\title{
"Budget planning with the development of the budget process in Ukraine"
}

\begin{tabular}{|c|c|}
\hline AUTHORS & $\begin{array}{l}\text { Kateryna Romenska (D https://orcid.org/0000-0001-6442-7802 } \\
\text { R http://www.researcherid.com/rid/AAE-8882-2019 } \\
\text { Victor Chentsov (D https://orcid.org/0000-0002-1109-8168 } \\
\text { R https://publons.com/researcher/1875835/victor-v-chentsov/ } \\
\text { Oleksandr Rozhko (D) https://orcid.org/0000-0001-8415-2084 } \\
\text { Vitaliy Uspalenko }\end{array}$ \\
\hline ARTICLE INFO & $\begin{array}{l}\text { Kateryna Romenska, Victor Chentsov, Oleksandr Rozhko and Vitaliy Uspalenko } \\
(2020) \text {. Budget planning with the development of the budget process in Ukraine. } \\
\text { Problems and Perspectives in Management, 18(2), 246-260. } \\
\text { doi:10.21511/ppm.18(2).2020.21 }\end{array}$ \\
\hline DOI & http://dx.doi.org/10.21511/ppm.18(2).2020.21 \\
\hline RELEASED ON & Wednesday, 17 June 2020 \\
\hline RECEIVED ON & Monday, 30 March 2020 \\
\hline ACCEPTED ON & Wednesday, 10 June 2020 \\
\hline LICENSE & $\begin{array}{l}(c) E Y \quad B \\
\text { This work is licensed under a Creative Commons Attribution } 4.0 \text { International } \\
\text { License }\end{array}$ \\
\hline JOURNAL & "Problems and Perspectives in Management" \\
\hline ISSN PRINT & $1727-7051$ \\
\hline ISSN ONLINE & $1810-5467$ \\
\hline PUBLISHER & LLC “Consulting Publishing Company "Business Perspectives" \\
\hline FOUNDER & LLC "Consulting Publishing Company "Business Perspectives" \\
\hline
\end{tabular}

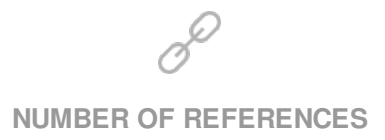

36
NUMBER OF FIGURES

6

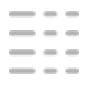

NUMBER OF TABLES

1

(C) The author(s) 2022. This publication is an open access article. 


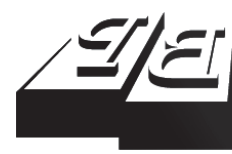

\section{BUSINESS PERSPECTIVES}

()

LLC "CPC "Business Perspectives" Hryhorii Skovoroda lane, 10, Sumy, 40022, Ukraine www.businessperspectives.org

Received on: $30^{\text {th }}$ of March, 2020 Accepted on: $10^{\text {th }}$ of June, 2020 Published on: $17^{\text {th }}$ of June, 2020

( ) Kateryna Romenska, Victor Chentsov, Oleksandr Rozhko, Vitaliy Uspalenko, 2020

Kateryna Romenska, Ph.D. in Economics, Associate Professor, Department of State, Local and Corporate Finance, University of Customs and Finance, Ukraine. (Corresponding author)

Victor Chentsov, D.Sc. (History), D.Sc. (Public Management and Administration), First Vice-Rector, University of Customs and Finance, Ukraine.

Oleksandr Rozhko, Doctor of Economic Sciences, Lecturer, ViceRector, Kyiv National Taras Shevchenko University, Ukraine.

Vitaliy Uspalenko, Professor, Department of Finance and Credit, Kharkiv National University of Construction and Architecture, Ukraine.
Kateryna Romenska (Ukraine), Victor Chentsov (Ukraine), Oleksandr Rozhko (Ukraine), Vitaliy Uspalenko (Ukraine)

\section{BUDGET PLANNING WITH THE DEVELOPMENT OF THE BUDGET PROCESS IN UKRAINE}

\begin{abstract}
The transition to future-oriented medium-term budget planning has been an important innovation in the budget process of Ukraine. Since then, the main budget indicators are calculated for the next three years with a forecast that allows for systemic reforms in several areas. This paper aims to identify problems of implementing budget planning for generating an envisaged and balanced budget in conjunction with the priorities of the state. The current status of budget planning and budget performance is analyzed by reviewing budget legislation, budget reporting, information-analytical and presentation data of state authorities and local governments, the experience of developed countries that have achieved some success in medium-term budget planning in terms of income and spending. The paper also reveals the features and advantages of medium-term budget planning based on the result; explores the approaches to transparent, effective, and high-quality use of budget funds with a limited potential of the state to increase tax revenues. The implementation of budget planning is due to the need for further development of the budget process in Ukraine towards increasing predictability, transparency, stabilizing the budget in the medium term, and solving important problems of efficient and high-quality use of budget funds for economic and social recovery.
\end{abstract}

\section{Keywords}

medium-term budget planning, budget parameters, transparency, efficient use of budget funds

\section{JEL Classification H50, H60, I00}

\section{INTRODUCTION}

The development of the budget process in Ukraine from the point of view of improving budget planning is gradual. This mainly concerns the creation of an appropriate legal framework focused on the requirements for the budget systems of developed countries, mainly member states of the Organization for Economic Cooperation and Development (OECD), which successfully implement public administration policies, and the European Union, where medium-term budget planning is considered the standard of sound budget planning. The focus of budget planning on a three-year perspective allows us to substantiate the vectors of budget policy, associate state priorities with budget opportunities, and focus on costs in relation to the expected results. Predictability of budget parameters aimed at implementing development priorities is an important direction of the budget process at the planning stage; it helps in ensuring predictability of reforms, transparency and openness, strengthening control over the use of budget funds, and improving the quality of budget services, budget stability and predictability, control over the level of government debt.

Thanks to the development of budget planning, it is possible to ensure long-term balance and stability of budgets, which is an impor- 
tant prerequisite for maintaining macroeconomic stability, which, in turn, creates the basic conditions for sustainable inclusive economic growth, strategic objectives, and welfare. The growth of government debt is mainly due to unrealistic planning of revenues and expenditures of the country's budget system and the lack of clearly defined fiscal policy priorities. Maintaining a balance between ensuring debt sustainability, long-term balance of the country's budget system, on the one hand, and sustainable socio-economic development, on the other hand, requires clear formation of the main budget characteristics and fiscal policy as a whole, as well as strict adherence to quantitative limits of budgetary parameters, which is an important means of reducing budget policy risks and improving the quality of the budget process in Ukraine.

\section{LITERATURE REVIEW}

The medium-term perspective is enshrined in the budget process of Ukraine, and work on budgets for the next planning year and two forecast years for all participants in the budget process begins in January when it is already possible to analyze how the previous year ended and ends in August preceding the planning year (Verkhovna Rada of Ukraine, 2018). The legislative documents governing the implementation of budget planning in Ukraine are the Budget Code of Ukraine, government strategies, resolutions of the Cabinet of Ministers of Ukraine, orders of the Ministry of Finance of Ukraine, and other legal documents. Budget planning is the first stage of the budget cycle, so the successful organization of the stages, such as approval, implementation and reporting, necessarily depends on the budget documents formed during this period - a budget declaration, budget requests of chief budget managers and the draft budget (Verkhovna Rada of Ukraine, 2010, 2020).

Budget planning is a component of budget management, which, along with other interrelated components, such as budget execution, budget accounting, budget reporting, and control over budget execution, is studied by Demianyshyn and Pohrishchuk (2017). The authors argue that a well-organized budget planning process involves mutually agreed relations and constructive cooperation of all participants at the state and local levels - from budgetary institutions to line ministries and departments - and plays an important role in determining priority areas of budget funds based on available budget resources.

According to the report on budget fulfillment in recent years, the State Budget of Ukraine is executed with a large budget deficit. The reason for this is a decrease in budget revenues and a significant increase in expenditures, which is mainly due to fluctuations in the hryvnia to the US dollar. Non-fulfillment of forecast calculations of the State Budget of Ukraine is due to its adjustment and changes in budget and tax legislation. Thus, in 2017, the Verkhovna Rada of Ukraine made changes to the state budget five times, and in 2018-2019, four times (Ministry of Finance of Ukraine, 2018; Ministry of Finance of Ukraine, 2019; Ministry of Finance of Ukraine, 2019a). The adjustment of fiscal policy parameters indicates the need for improved budget revenue and expenditure planning, contributing to the development of the economy and human well-being.

It is fundamentally important at the planning stage to take into account possible risks, threats, and dangers of various areas of the country's socio-economic development (Sharov \& Reznikova, 2019). The main problems of Ukraine in recent years are the temporarily occupied territories, high dependence on energy imports, inefficient export structure, reduced labor resources due to labor migration, etc. These trends threaten financial security, affect the country's budget system, and complicate budget planning in the medium term. On the other hand, based on clearly defined fiscal policy priorities, medium-term budget planning ensures the budget process continuity, strengthening the interdependence of financial security and maximum predictability and stability of budget execution. According to Chugunov, Makohon, and Krykun (2019), the income and expenditure budget planning should be drawn up in such a way as to ensure the achievement of strategic goals and objectives of sustainable socio-economic development of a country as a whole and its administrative-territorial entities in particular while maintaining budgetary stability and balance. 
Like annual plans, sliding medium-term plans also identify investment projects financed from budgetary sources to the possible extent. When planning a long-term three-year budget, it is important to monitor and analyze how the previous year ended, how clearly the budget was executed, whether there are emergency and unbudgeted expenditures, and whether the country goes beyond the planned financial framework, and only then calculate expenditures for subsequent years. Timely adoption of the budget before the beginning of the next budget year is a prerequisite for its quality implementation (Davydenko \& Horobchuk, 2019).

The main challenge for many countries is their desire to increase the budget by expanding the tax base. However, in the context of slowing economic growth, such fiscal policy leads to unbalanced budget revenues and expenditures and makes it difficult to keep the budget deficit within the statutory framework. The need for balanced revenues and expenditures leads to borrowing by the state and the formation of government debt. Budget balance and government debt formation were debatable issues among researchers - representatives of various economic schools - from complete rejection to the use of credit instruments to cover the budget deficit and stabilize the state's economy. Modern concepts are based on the fact that public finance aims to ensure macroeconomic balance through budgetary regulation of the economy, i.e., the budget deficit is acceptable, can be an effective tool for regulating the economy, but requires constant monitoring and management. Meanwhile, the identified priorities of the state debt policy should be justified, and government borrowing should be aimed at implementing the dominant directions of social development (Lysiak, Kachula, Hrytsenko, Romenska, \& Deikalo, 2015).

The transition to strategic budget planning is new for Ukraine but is being successfully implemented by territorially close countries of the post-Soviet space: the Republic of Belarus, the Russian Federation, and the Republic of Kazakhstan. These countries have achieved some success in reforming public administration systems and strengthen their competitiveness. The experience of the Republic of Belarus on the budget execution results in recent years shows that long-term budget planning allows achieving the planned results in combination with a favorable foreign economic infrastructure. Thus, according to the results of 2019, inflation does not exceed the forecast value and is $105.6 \%$, gold and foreign exchange reserves increase, and the balances of government funds are formed, ensuring sustainable implementation of national and local budgets in 2020 . Conservative budget policy, budget execution with a surplus, and maintaining the stable budget system contributed to the implementation of the basic parameters of the forecast of socio-economic development. The key to successful budget execution in the Republic of Belarus is stability, and the necessary condition for maintaining sustainable economic growth and increased innovation activity in the medium term is ensuring macroeconomic stability, that is predictability of domestic economic conditions, stable and low inflation, a stable and clear tax system (Council of Ministers of the Republic of Belarus, 2020; Ministry of Finance of the Republic of Belarus, 2019).

In 2020-2024, the Republic of Kazakhstan's socio-economic policy is based on achieving longterm goals of improving the population welfare and ensuring sustainable economic growth in implementing the Kazakhstan 2050 Strategy and the Strategic Plan for Development of Kazakhstan until 2050. The problems of ensuring social security and employment, as well as reduced inflation and price stability, are still being addressed. Given the implementation of the 100 Concrete Steps Nation's Plan on five institutional reforms and President's Five Social Initiatives, the key priorities of socio-economic policy of the Republic of Kazakhstan are macroeconomic stability, development of economic sectors, stimulating private entrepreneurship, improved quality of human capital, balanced regional development, an effective system of public administration, and international integration. Thanks to the result-oriented budget planning, it is planned to implement one of the main objectives of the budget policy, namely, to improve the quality of public services and the implementation of public functions, including within the framework of the Digital Kazakhstan Program.

This program ensures the highest possible optimization of public service delivery processes, reducing deadlines and list of documents, eliminating 
duplicate procedures and their full translation into electronic format. Priority is given to financing measures to improve the conditions for doing business and improving Kazakhstan's position in international rankings (Republic Budget Commission of the Republic of Kazakhstan, 2019, 2019a).

As to the RF federal budget's main characteristics for the planned 2020 and forecast 2021 and 2022, the projected inflation rate should not exceed 3\% (in December 2020, compared to December 2019). The budget for 2020-2022 is planned with a surplus (State Duma of Russian Federation, 2019).

Figure 1 shows the Republic of Belarus, the Russian Federation, and Ukraine's budget execution results in terms of revenues and expenditures. As one can see, the Republic of Kazakhstan budget planning is the most reasonable since the country has the smallest fluctuations between planned and implemented parameters. Ukraine has the least informed budget planning, especially in 2018-2019. Therefore, it is necessary to take measures to ensure conditions for sustainable economic development and maintain macroeconomic stability with unconditional fulfillment of expenditure commitments and implementation of key priorities of Ukraine's socio-economic development (Ministry of Finance of the Republic of Kazakhstan, 2019;
Ministry of Finance of the Republic of Belarus, 2020; Ministry of Finance of Russian Federation, 2020; Ministry of Finance of Ukraine, 2019a).

The goals and objectives of budget planning are to increase the potential for economic development by contributing to the achievement of national development goals, increasing investment activity, and forming a fair, competitive environment. Effective government control involves implementing budget planning based on the following objectives: setting up government programs to achieve development goals, integrating measures with measurable results, clear division of responsibilities and powers, and design principles and management mechanisms.

When assessing budget deficits (surplus) of the studied countries (see Figure 2), one can note that the budget of the Republic of Belarus and the Russian Federation (except 2017) is executed with a surplus; in the Republic of Kazakhstan, the deficit varies, and Ukraine has budget deficit, the share of which in GDP is growing every year, which is a negative trend (Ministry of Finance of the Republic of Kazakhstan, 2019; Ministry of Finance of the Republic of Belarus, 2020; Ministry of Finance of Russian Federation, 2020; Ministry of Finance of Ukraine, 2019a).

Source: Constructed by the authors based on the Ministry of Finance of the Republic of Kazakhstan (2019), Ministry of Finance of the Republic of Belarus (2020), Ministry of Finance of the Russian Federation (2020), and Ministry of Finance of Ukraine (2019a).

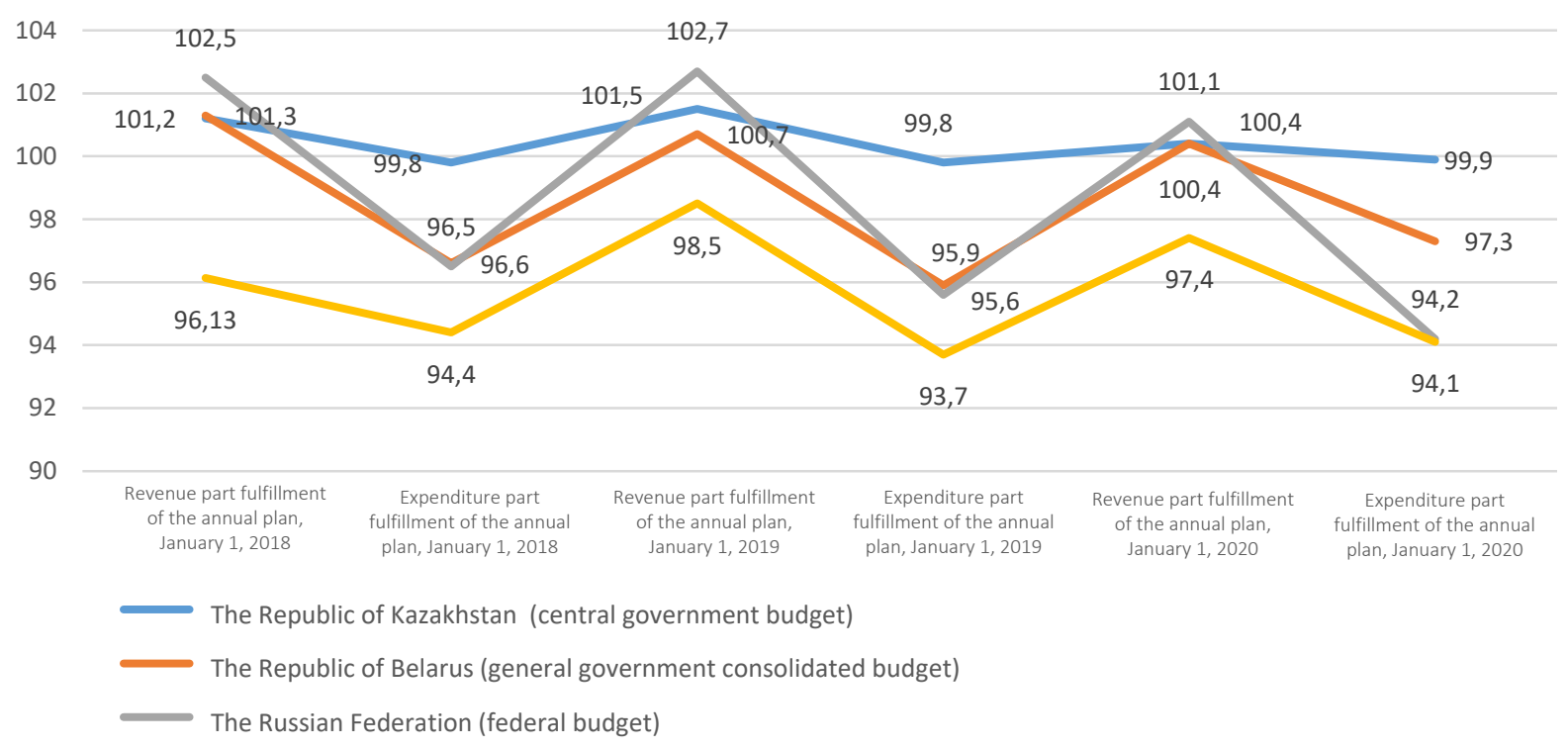

Figure 1. Execution of revenue and expenditure parts of budgets, \% 

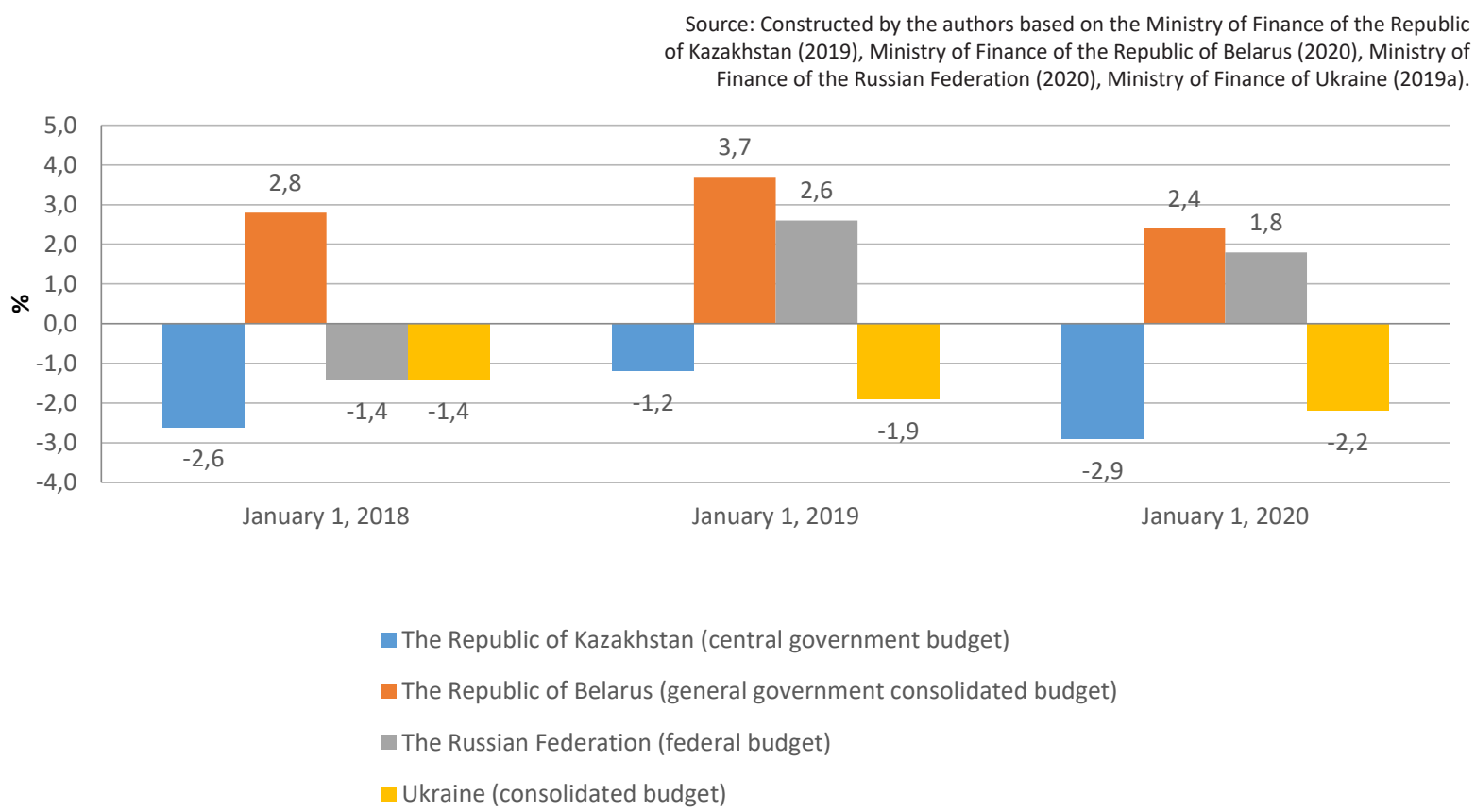

Figure 2. The share of budget deficit (-) and surplus (+) in GDP, \%

Maintaining positive trends in the country's economy and concentrating budget funds for solving priority tasks of socio-economic development require balanced execution of all budgets; maintaining the growth of public debt and keeping its size at a safe level; ensuring the stability of tax legislation; refusal of ineffective tax benefits; developing an institute of non-tax budget revenue administration; reduced budget participation in all types of state support of the real sector of the economy; concentration of budget funds in areas ensuring the achievement of strategic goals of the country's socio-economic development; improving the program-targeted budget planning method; increased social orientation of expenditures; taking measures to improve the quality of life, well-being of public sector employees; support for low-income citizens; improved fiscal risk management system of enterprises with obligations to the budget; ensuring the transparent and open budget process.

The absorption of allocated budget funds can assess the quality of budget planning and execution for the relevant budget year; the amount of redistributed funds of the approved budget, indicating the reasons and justifications for such fund redistribution; no facts of an increase in the estimated cost of a budget investment project and the reasons for the increase in its value; no receivables and payables; no violations of budget legislation; the implemented meas- ures to eliminate the causes of violations of budget legislation; achieving performance indicators of budget programs; and evaluation of the budget program effectiveness (Lukianenko, 2017).

The number and amount of violations of budget legislation are quantitative indicators that determine the problem of inefficient and ineffective use of budget funds. Identified violations for the relevant period may occur in such cases: when crediting funds to the budget (revenue part); when using budget funds; in accounting and financial reporting; in case of non-compliance with the established deadlines, the order of the execution of budgetary procedures and public procurement procedures, including a choice of the public procurement organizer. The indicators of the quality of control over the compliance with budget legislation are the percentage of violations in the total amount of controlled budget funds in the reporting period; the total amount of identified violations of budget legislation; the amount of controlled budget funds; the share of identified expenditures that do not comply with the principle of efficiency in total costs.

The form of preliminary control over compliance with budget legislation, which prevents cases of inefficient, ineffective, and inappropriate use of budget funds, plays an important role in budget control. Such control is carried out by the bodies 
of the State Treasury Service of Ukraine in the process of treasury servicing of budgets by revenues and expenditures. The development of modern technologies for the budget execution of Ukraine's budget system is inextricably linked with the development of treasury services and the creation of a system of treasury payments. Directly performing the main functions, namely, providing treasury services to budgets, the treasury bodies carry out constant budgetary monitoring using available information resources and data obtained as a result of interdepartmental interaction with other participants in the budget process: bodies of the State Fiscal Service of Ukraine, the State Audit Service of Ukraine, local state administrations, local governments, public treasurers and their subordinate institutions, etc., thereby preventing financial violations by the budget process participants. Figure 3 shows the number by types and the amounts of warnings for managers and recipients of state and local budgets, defined by the State Treasury Service of Ukraine. The growth of indicators is, on the one hand, a negative trend of violations of budget legislation, which are biased but can occur, and on the other hand, indicates the effective work of the State
Treasury in identifying such cases and preventing them (Treasury of Ukraine, 2019).

During the study period, the number of warnings to managers and recipients of state and local budgets from the State Treasury Service of Ukraine grows (see Figure 4). The main reasons for warnings when registering liabilities and financial liabilities include non-compliance by managers and recipients of budget funds with the requirements for the execution of submitted documents (contracts, invoices, and certificates of work performed); submission of budget commitments and financial commitments to the Treasury in violation of specified deadlines; violation of legislative requirements in public procurement. The main reasons for issuing warnings when accepting payment orders include misuse of budget funds (inconsistency of the specified code of expenses' economic classification with the economic characteristics of payment); incorrect execution of payment orders (incorrect details); lack of relevant budget commitments and financial commitments in the accounting of the Treasury bodies. These reasons lead to inefficient use of budget funds, and the

Source: Constructed by the authors based on the Treasury of Ukraine (2019).

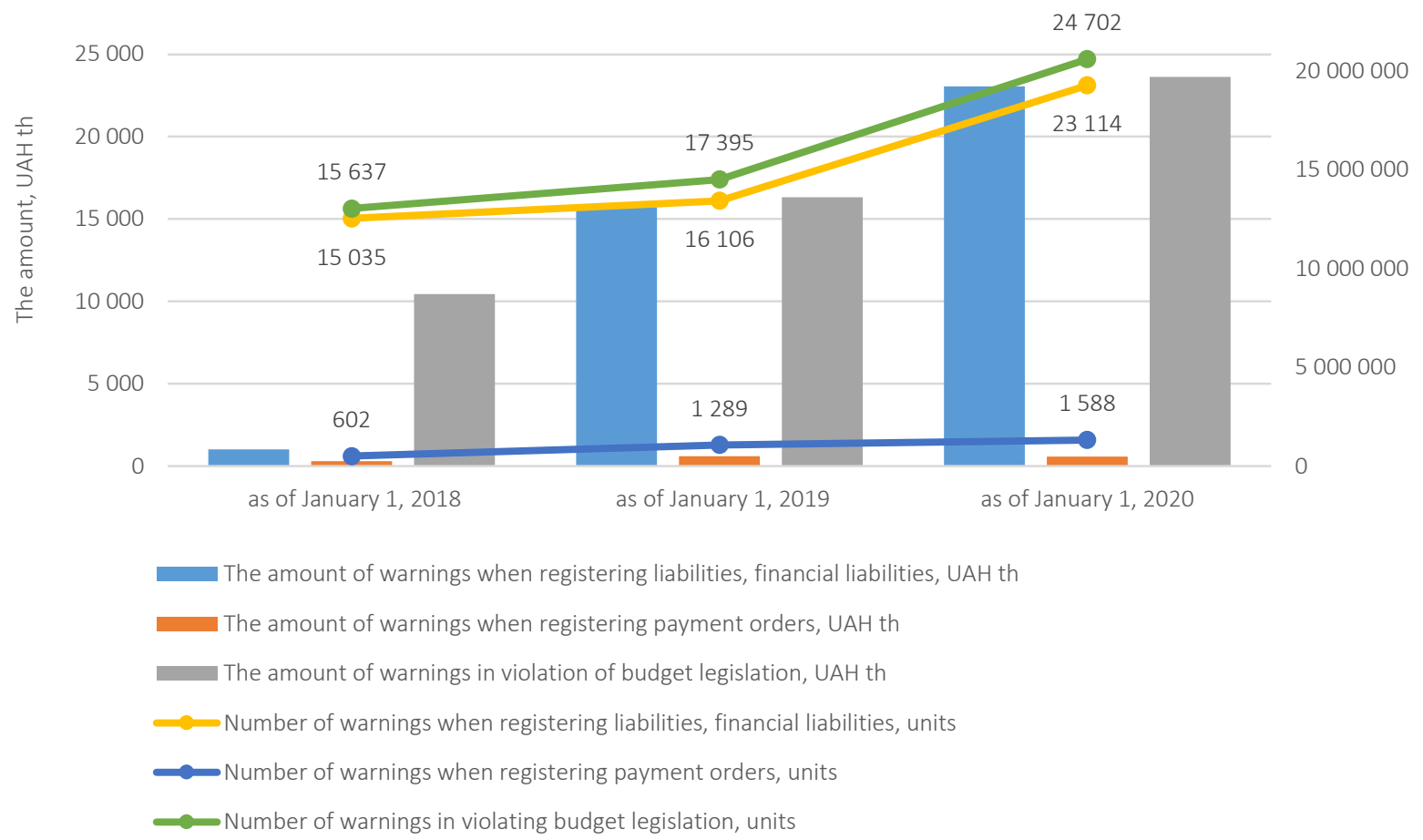

Figure 3. The number and the amounts of warnings for managers and recipients of state and local budgets, identified by the State Treasury Service of Ukraine 


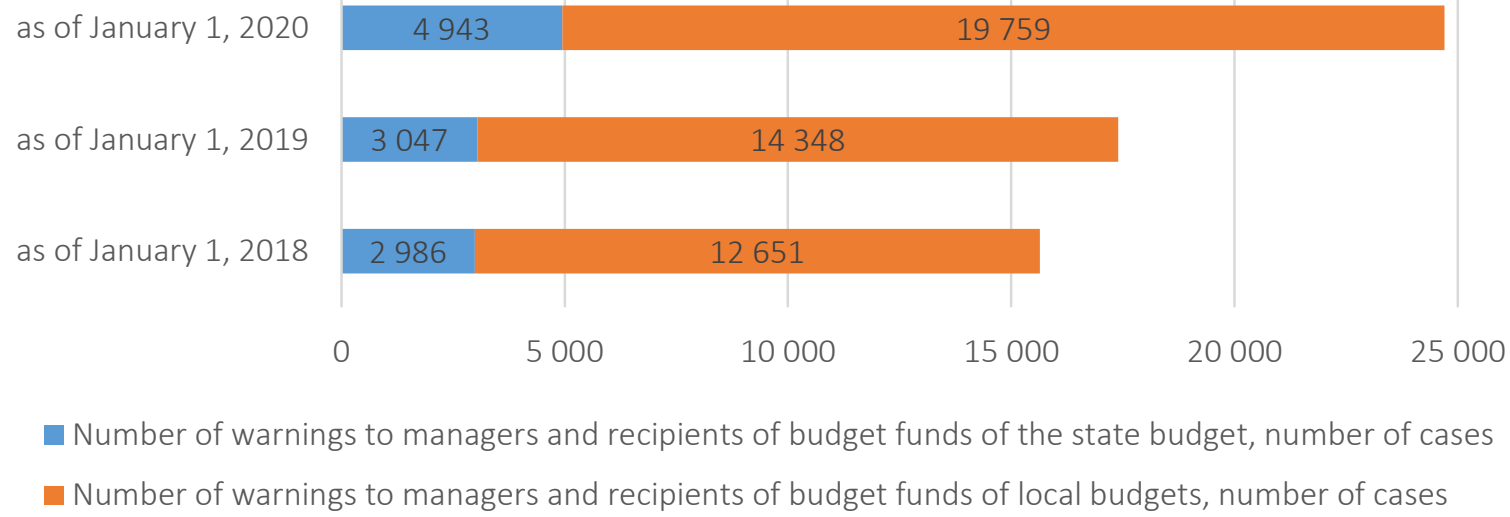

Figure 4. Number of warnings from the State Treasury Service of Ukraine's bodies to managers and recipients of state and local budgets about improper fulfillment of budget legislation, number of cases

Treasury of Ukraine prevents the occurrence of such cases (Treasury of Ukraine, 2019).

Qualitative measures indicating the problem of misallocation of budget funds include: the effectiveness of function (power) execution by managers and recipients of budget funds; the relationship between budget funds and the quality of their use; competition on the market of services provided at the expense of budget funds (distribution of state and local tasks between budget fund managers); reliability of budget reporting indicators; simplification of the format of budget submission for citizens and reports on budget execution; understandability for citizens of the information published on official information resources about the results of activities of public authorities, local governments; free access to educational and information materials on budgeting practices for citizens, as well as popularization of public control and knowledge on budget issues and tools for participation in public finance management among various social groups; an internal audit of budgetary institutions, properly conducted and aimed at providing a leader with objective and independent conclusions and recommendations on the internal control effectiveness (Radionov, 2019).

\section{BASIC STATEMENTS}

The maximum use of the potential of long-term budget planning and using a program-targeted method allows planning the budget with an empha- sis on the effective and efficient use of budget funds in the medium term. The advantage of the medium-term result-oriented budget planning is the increased interest of public authorities, local governments not only in the targeted but also in the qualitative use of budget funds. Therefore, today there are favorable conditions for the wise and efficient use of budget funds to ensure the receipt of quality indicators based on the results of budget services. However, in the budget process, there are times when budget decisions are influenced by personal, political, and other factors that weaken the adoption of sound budget decisions. This explains the interdependence when the efficiency and effectiveness of budget funds are affected by the quality of performance of their own and delegated powers by public authorities, local governments, and other participants in the budget process. Figure 5 represents stakeholders in increasing the efficiency and effectiveness of the use of budget funds. Based on the degree of influence and the level of interest, the position of bodies, organizations, individuals and parties that can influence, can be influenced, or who believe that they are influenced by a decision or action related to the efficient and effective use of budget funds is determined.

When it comes to the level of interest in solving the problem, the use of strict measures for overspending and inefficient use of funds, and prosecution of individuals for financial offenses will ensure the efficient use of budget funds, but at the same time will increase the demands and responsibilities of public authorities and local governments as to ensuring ra- 
Source: Authors' suggestions based on Zubenko (2017), Demianyshyn and Pohrishchuk (2017).

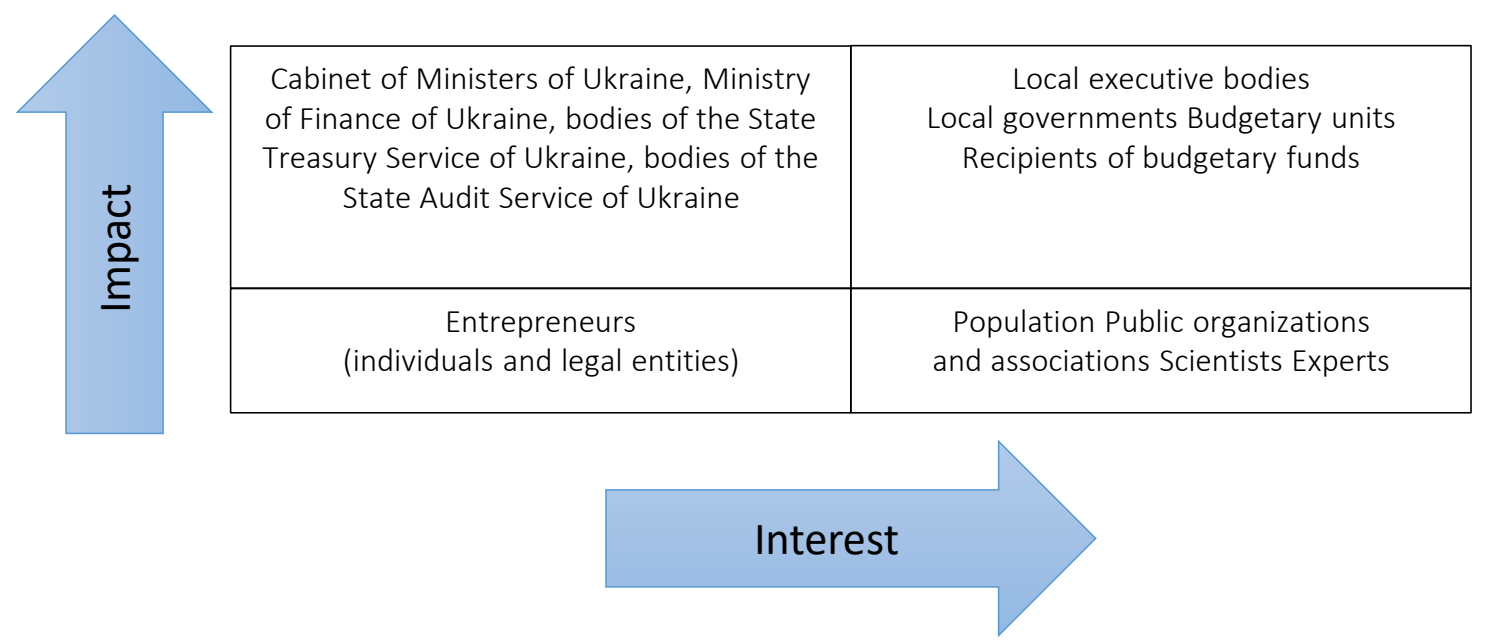

Figure 5. Stakeholders in improving the efficiency and effectiveness of the use of budget funds

tional and prudent use of funds. This, in turn, reduces the interest of the participants in the upper right margin. Besides, their interest in the efficient use of budget funds and quality provision of budget services reduces the lack of motivation in the remuneration system, as employees of budgetary institutions receive fixed wages.

While ensuring the principle of the budget efficiency and effectiveness, it is necessary to modernize the process of state social support for citizens, which should aim to improve the quality of human capital: life and welfare of citizens through an effective system of social protection and social security. Important measures to increase the efficiency of budget planning, aimed at improving human well-being and strengthening the social orientation of the budget, include increasing the share of social expenditures in total budget expenditures, maintaining minimum standards for budget support of social spending, ensuring the necessary budget funding. Building an econometric model confirmed the following: first, the relationship between tax revenues and expenditures of the State Budget of Ukraine; second, the significant impact of the main priority areas of budget expenditures: social protection and social security expenditures, defense and security expenditures, transfers to local budgets, debt service expenditures on the expenditure part of the State Budget of Ukraine (see Figure 6).

Source: Constructed by the authors based on the materials of the Ministry of Finance of Ukraine $(2018,2019,2019 a)$.

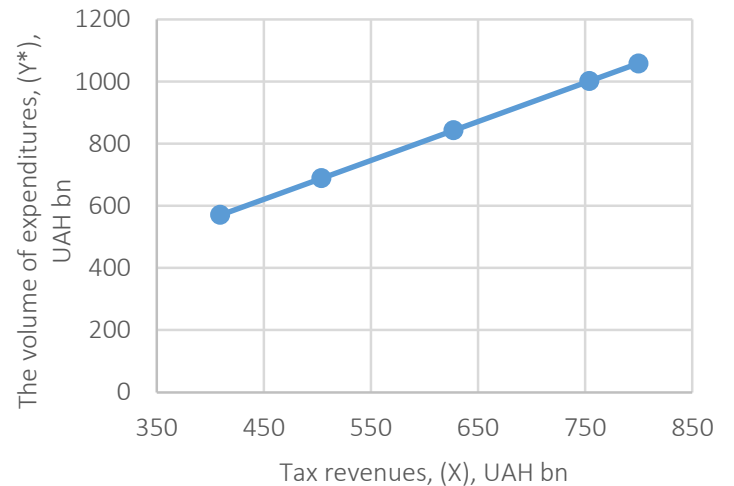

- The volume of budget expenditures influenced by tax revenues

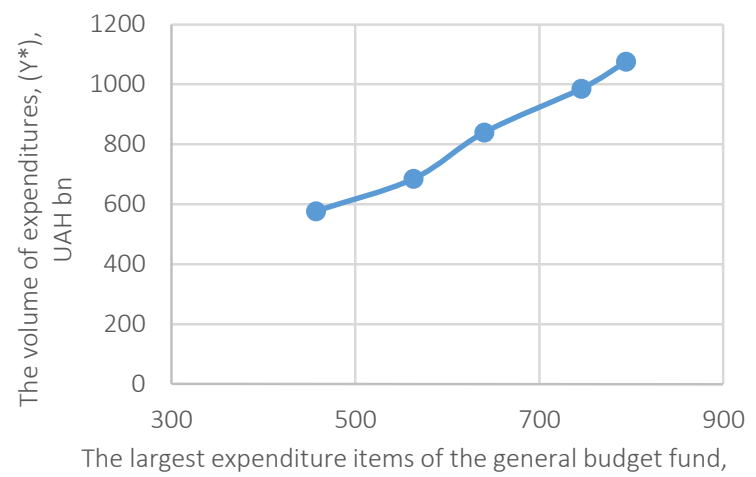

$(\mathrm{X})$, UAH bn

- The volume of budget expenditures influenced by the largest expense items of the general budget fund

Figure 6. The amount of the State Budget of Ukraine's expenditures influenced by tax revenues and the largest expenditure items of the general budget fund, UAH bn 
The dependence of the expenditure of the State Budget of Ukraine on tax revenues is evidence of the effective fiscal policy of the state on the formation of its own revenue base. With an increase in tax revenues per unit, the expenditure potentially increases by UAH 1.3. The determination coefficient for this model is $R^{2}=99.7 \%$. The model of the impact of tax revenues on the expenditure budget is only $0.3 \%$ due to factors beyond its borders, including random ones. For the model of the impact of the largest items on the expenditure budget, the determination coefficient is $R^{2}=99.2 \%$; therefore, the model is $0.8 \%$ due to factors beyond its limits, including random ones. The equation shows that with an increase in the largest items of expenditures of the overall budget, that is, expenditures on social protection and social security, expenditures on defense and security, and transfers to local budgets per unit, the volume of expenditures will increase by UAH 0.2 , and with an increase in debt servicing costs per unit, the expenditure volume of the State Budget of Ukraine will increase by UAH 0.1. However, given the limited potential to increase tax revenues, it is important to reasonably distribute the expenditure, based on the state development priorities. Otherwise, the state, unable to cover the costs, is forced to seek external assistance, which is undesirable (Ministry of Finance of Ukraine, 2018, 2019, 2019a).

In the current development of the budget process, the need to fulfill the state's obligations to citizens determines the increase in the efficiency and quality of budget services, including social assistance, and monitoring the impact of positive changes on efficiency statistics, quality and transparency of budget fund usage. The experience of developed countries shows that by providing population not with monetary but with in-kind targeted assistance, the quality of social services improves. Only in this way, when the service is provided in an amount sufficient for a family and an individual, the effectiveness of the provision of these services can be calculated. In-kind assistance, direct or through reimbursement, is the most effective and efficient use of budget funds compared to social assistance, which is paid in cash in the form of regular payments and can be used by households or individuals for purposes other than intended. In Ukraine, there is an example of one-time in-kind assistance in the budget, Baby Package, which is provided together with childbirth allowance. It is planned that in 2020, 331 thousand families will receive such assistance. Thus, one of the assumptions is that in-kind assistance is the most convenient in terms of savings for budget and effective for recipients since a household or an individual can purchase goods and services for a certain amount and receive compensation for them. This type of assistance can also be used to provide medical, dental, and other treatment, inpatient care, nursing care, long-term care due to illness, injury, disability, care for the elderly, assistance to low-income families, etc. For example, the state indirectly can provide social security by providing tax benefits, wage subsidies, etc. (Verkhovna Rada of Ukraine, 2020).

The experience of Israel, the Republic of Kazakhstan, and the Republic of Belarus, the countries with developed social policies on the use of social ID-cards, is interesting. Work on the introduction of such cards is being carried out in the pilot regions of the countries. These include school meals, travel by public transport, targeted social assistance, free medication, etc. Besides, it is worth paying attention to the experience of implementing housing certificates for workers in education, health care, culture, police, etc. It should be noted that the use of such cards ensures the unimpeded receipt of the service by users, and control over the provision of services by the state and local governments, to identify problems on time (Ministry of Finance of the Republic of Kazakhstan, 2019a).

The experience of the Republic of Belarus shows that assisting low-income and vulnerable social groups in the form of services and goods, such as legal advice, housing, home care, food, clothing, etc., provides not only transparent, targeted and high-quality use of budget funds but also prevents cases of waste and fraud related to the appointment of cash assistance. In-kind social aid provides low-income citizens with the necessary basic goods and services and motivates and stimulates them to earn additional funds for secondary needs, without relying on financial assistance from the state (Council of Ministers of the Republic of Belarus, 2015).

In the Russian Federation, the improvement of social support mechanisms and provision of public 
services in the social sphere using electronic certificates are an additional step towards the development of modern budget execution technologies. In regional practice, there are examples of successful use of these certificates, which allows ensuring: rational use of budget funds (cash on demand); balance of intended use and freedom of choice of a citizen (the ability to choose goods, services, their suppliers, as well as convenient places and times of purchase, including via the Internet, which is especially important for people with limited mobility); reduction in administrative costs (due to the lack of the need for procurement under competitive procedures and the formation of inventory). Moreover, the further development of budget execution technologies in terms of fulfilling state regulatory obligations provides for actual relevant payments only after confirming the data on their specific recipients based on reliable information from state information systems in the field of social security (Government of Russian Federation, 2019).

\section{DISCUSSION}

Effective budget planning implementation in the context of the development of the budget process leads to a further search and application of advanced technologies for the allocation of budget funds. This increases the emphasis on the results of budget funds and ensures the provision of quality budget services in various areas of public life. Budget planning by the program-targeted method is not a new measure, but it is the best budgeting practice. This is confirmed by many years of the world experience. The experience of the Republic of Belarus, which successfully implements the State Program "People's Health and Demographic Security of the Republic of Belarus", shows that the increase in life expectancy is the main indicator of achieving the set goals. It is worth paying attention to the experience of defining tasks for 2016-2020, which include improved efficiency of the health care system; improved quality of health care services; reduced mortality, especially in working age; creating conditions to increase life expectancy; population stabilization. The funds provided in the budget will be aimed at: implementing the latest modern technologies of early diagnosis, prevention, treatment and rehabilitation of patients in the practice of the health care system; organizing preventive measures for early detection of risk factors for socially significant diseases, improving the quality of their diagnosis, treatment and rehabilitation of patients; increasing the availability of medical care to the population. Among the areas of the RF budget policy are reduction in mortality due to prevention and increased detection of diseases in the early stages; improving the primary care system; improving medical infrastructure and eliminating the shortage of medical workers; equipment and re-equipment of oncology and cardiovascular centers; providing assistance and creating favorable conditions for the elderly. The experience of the Republic of Kazakhstan shows that the population has access to quality medical services through the introduction of electronic health passports. The state budget provides measures for the prevention and monitoring of major socially significant non-communicable diseases, provides conditions for sanitary and epidemiological well-being, increases information responsibility of the population for their health by rationalizing nutrition and promoting a healthy lifestyle, developing a sanitary and physical culture.

In addition to the program-targeted method of budgeting in health care, foreign countries resort to alternative budgeting, "green", inclusive, and gender-oriented budgeting to obtain results. The experience of such countries is interesting and useful to apply and shows that a situation is possible in which it is known that a certain pattern exists, but is not used in budget planning. After making some changes to the budget planning technology, using budget funds will be cost-effective. For example, to improve the nation's health, the Israeli government resorted to the practice of exempting the purchase of fresh fruit and vegetables from VAT. In other words, the reduction in VAT revenues was offset by lower healthcare costs and morbidity prevention through the individual consumption of healthy foods rich in vitamins and nutrients. Table 1 gives some examples ensuring the efficient use of budget funds for health care, and the accompanying positive expected results in other areas.

Besides, it is worth using the positive developments in the implementation of gender-oriented budgeting in the budget process. International ex- 
Table 1. The list of alternative areas of budget financing and expected results of the efficient use of budget funds

Source: Authors' suggestions based on the Organisation for Economic Co-operation and Development's (2020) data.

\begin{tabular}{|c|c|}
\hline Contents of the areas & Expected result \\
\hline $\begin{array}{l}\text { Large-scale technological modernization of key industries with the introduction of } \\
\text { integrated information and technology platforms, digital technologies }\end{array}$ & $\begin{array}{l}\text { Morbidity reduction } \\
\text { Increased export potential and labor productivity }\end{array}$ \\
\hline $\begin{array}{l}\text { Strengthening the requirements for environmental friendliness of enterprises, } \\
\text { stimulating investment in green technologies, environmental safety, the } \\
\text { development of alternative energy sources, a waste-free economy and the } \\
\text { conservation of species }\end{array}$ & $\begin{array}{l}\text { Morbidity reduction } \\
\text { Improved quality of water and land resources } \\
\text { GDP energy intensity reduction }\end{array}$ \\
\hline $\begin{array}{l}\text { Strengthening measures aimed at preventing and promoting healthy lifestyles, } \\
\text { increasing the availability of sports and physical culture based on existing facilities, } \\
\text { providing the population with quality goods, including examination of food, } \\
\text { medicines, drinking water, children's goods, and medical services }\end{array}$ & $\begin{array}{l}\text { Morbidity reduction } \\
\text { Increased life expectancy }\end{array}$ \\
\hline $\begin{array}{l}\text { Use of energy-efficient and energy-saving technologies for insulation and lighting } \\
\text { of residential and non-residential premises }\end{array}$ & $\begin{array}{l}\text { Morbidity reduction } \\
\text { Saving of natural resources } \\
\text { Lower energy costs }\end{array}$ \\
\hline $\begin{array}{l}\text { Given the demand for e-cigarettes, taxes on e-cigarettes, alcohol and low-alcohol } \\
\text { products can be gradually increased }\end{array}$ & $\begin{array}{l}\text { Morbidity reduction } \\
\text { Increased life expectancy } \\
\text { Growth of tax revenues to the budget }\end{array}$ \\
\hline $\begin{array}{l}\text { Establishment of tax benefits with a mandatory assessment of each tax benefit, } \\
\text { such as establishing tax benefits for companies whose employees work remotely }\end{array}$ & $\begin{array}{l}\text { Morbidity reduction } \\
\text { Saving paper, fuel, and other resources } \\
\text { Improving the infrastructure of human settlements } \\
\text { Road quality improvement } \\
\text { Traffic jam reduction } \\
\text { Reduced car emissions }\end{array}$ \\
\hline
\end{tabular}

perience shows that such budgeting is an effective tool for distributing and redistributing budget funds and, by ensuring gender equality and social gender justice, equal access to public goods for different social groups of women and men, improves everyone's life and the country's economy whole. Gender-based budgeting allows efficient use and saving of budget funds, ensuring equal rights for the participation of men and women in political and economic life, as well as equality in healthcare, education, etc. (Klatcer \& Ivanina, 2019).

The education sector is a priority area of budget policy in the studied countries and is fundamental for further development. It pays particular attention to ensuring the accessibility and quality of education. The goals of the Education and Youth Policy State Program of the Republic of Belarus for 2016-2020 are improved quality and accessibility of education compared to the needs of the innovative economy, the needs of society, the needs of citizens; development of youth potential, its involvement in socially useful activities. The Strategic Development Plan of the Republic of Kazakhstan and the State
Program for the Development of Education and Science of the Republic of Kazakhstan pay attention to both preschool education and the development of secondary, technical, vocational and higher education. The introduction of elements of the development of new technologies, scientific innovations, mathematical modeling, programming, and robotics into educational programs has been ensured. In higher education, the introduction of the dual education principles and the reorganization of higher education institutions into non-profit joint-stock companies have been continued, which will attract additional investment for the development of universities and remove the burden from the budget.

Expenditure financing within the framework of state programs is carried out, taking into account the implementation of priority program activities, which provides a clearer connection with budget policy objectives and the concentration of budget expenditures in priority areas of socio-economic development. Thus, the most significant amount of budget funding falls on state socio-economic programs. Measures tak- 
en in the field of fiscal policy will continue to be aimed at increasing the share of program expenditures. In Ukraine, despite the transition to budgeting by the program-targeted method, its format does not fully comply with the program. Within the framework of Ukraine's budget legislation, the program classification of expenditures is only one of the approved classifications, along with the functional, economic, and departmental classifications of budget expendi- tures. While in countries successfully developing program budgeting (e.g., Austria, Australia, and France), the program structure of budget expenditures is the main, and in some cases, the only one. In this regard, the development and improvement of targeted planning based on state and local programs remains one of the key areas for improving the quality of the budget process and the efficient budget use in the future (Zubenko, 2017).

\section{CONCLUSION}

The study results enabled us to determine that in the context of modernizing the budget process, it is necessary to conduct a balanced macroeconomic policy using economic incentives and restrained fiscal policy. Of particular importance is the problem of a balanced budget, which requires a search for internal reserves to ensure access to the sustainable development path. One of these vectors is to ensure effective medium-term budget planning based on international experience. The experience of the Republic of Belarus, the Republic of Kazakhstan, and the Russian Federation show that to achieve the priorities and goals outlined in the strategic budget planning documents, and there is a need for a qualitative leap in socio-economic development with limited budget resources, which significantly increases the relevance of developing measures to modernize the budget process and to develop budget planning. Ukraine has the lowest rates in terms of revenues and expenditures compared to the budget execution indicators of the selected countries.

Along with the indicated areas, which are already being implemented in Ukraine and require further improvement, the distinctive features of the best foreign practices in budget planning development are implementation and constant review of budget spending; public participation in the budget process; developing a system for strategic planning of budget investments; improved completeness and quality of public sector financial reporting; digitalization of the public administration system and the budget process, the use of the latest result-oriented budgeting technologies. Focusing on budget performance is an integral attribute of a modern budget planning system. The formation of a full-fledged budget planning system requires significant time and planning in implementing reforms, changes in the management culture, interest, support, and constant attention from state bodies and local self-governments.

\section{AUTHOR CONTRIBUTIONS}

Conceptualization: Kateryna Romenska, Victor Chentsov, Oleksandr Rozhko, Vitaliy Uspalenko.

Data curation: Kateryna Romenska.

Formal analysis: Kateryna Romenska.

Investigation: Oleksandr Rozhko, Vitaliy Uspalenko.

Methodology: Victor Chentsov, Oleksandr Rozhko, Vitaliy Uspalenko.

Project administration: Kateryna Romenska.

Resources: Victor Chentsov, Vitaliy Uspalenko.

Supervision: Victor Chentsov, Oleksandr Rozhko.

Visualization: Oleksandr Rozhko, Vitaliy Uspalenko.

Writing - original draft: Kateryna Romenska.

Writing - review \& editing: Victor Chentsov, Oleksandr Rozhko, Vitaliy Uspalenko. 


\section{REFERENCES}

1. Chugunov, I., Makohon, V., \& Krykun, T. (2019). Budget strategy in the conditions of economic globalization. Problems and Perspectives in Management, 17(3), 101-110.

http://dx.doi.org/10.21511/ ppm.17(3).2019.08

2. Council of Ministers of the Republic of Belarus. (2015). O reformirovanii sistemy upravleniya gosudarstvennymi finansami Respubliki Belarus. Postanovleniye Soveta Ministrov Respubliki Belarus ot 23 dekabria 2015 № 1080 [On the reform of the public finance management system of the Republic of Belarus. Decree of the Council of Ministers of the Republic of Belarus of December 23, 2015 No. 1080]. (In Russian). Retrieved April 4, 2020 from http://www. minfin.gov.by/upload/bp/strategy/ post_231215_1080.pdf

3. Council of Ministers of the Republic of Belarus. (2020). O Gosudarstvennoy programme "Upravleniye gosudarstvennymi finansami $i$ regulirovaniye finansovogo rynka" na 2020 god $i$ na period do 2025 goda. Postanovleniye Soveta Ministrov Respubliki Belarus ot 12 marta 2020 № 143 [On the State Program "Public Finance Management and Financial Market Regulation" for 2020 and for the period until 2025. Decree of the Council of Ministers of the Republic of Belarus of March 12, 2020 No. 143]. (In Russian). Retrieved April 4, 2020 from http://www.minfin.gov.by/upload/ bp/act/postsm_120320_143.pdf

4. Council of the Republic of Belarus. (2018). Ob utverzhdenii otcheta ob ispolnenii respublikanskogo biudzheta za 2018 god. Zakon Respubliki Belarus ot 17 iyulia 2018 g. № 116-Z [On approval of the report on the implementation of the republican budget for 2017. The Law of the Republic of Belarus dated July 17, 2018 No. 116-Z]. (In Russian). Retrieved April 4, 2020 from http://www. minfin.gov.by/upload/budget/act/ zakon_170718_116z.pdf

5. Council of the Republic of Belarus. (2019). Ob utverzhdenii otcheta ob ispolnenii respublikanskogo bjudzheta za 2018 god. Zakon Respubliki Belarus ot 17 iyulia $2019 \mathrm{~g}$. № 215-Z [On approval of the report on the republican budget execution for 2018. The Law of the Republic of Belarus dated July 17, 2019 No. 215-Z]. (In Russian). Retrieved April 4, 2020 from http://www. minfin.gov.by/upload/budget/act/ zakon_170719_215-3z.pdf

6. Davydenko, N. M., \& Horobchuk, M. V. (2019). Medium-term planning in budgetary policy improvement in Ukraine. Scientific Bulletin of the International Humanities University, 38, 54-59. Retrieved April 3, 2020 from http://www. vestnik-econom.mgu.od.ua/journal/2019/38-2019/8.pdf

7. Demianyshyn, V. H., \& Pohrishchuk, H. B. (2017). Biudzhetnyi menedzhment [Budget management] (532 p.). Ternopil: TNEU. (In Ukrainian)

8. Dudchyk, O., Matvijchuk, I., Kovinia, I., Salnykova, T., \& Tubolets, I. (2019). Financial literacy in Ukraine: from micro to macro level. Investment Management and Financial Innovations, 16(4), 240253. http://dx.doi.org/10.21511/ imfi.16(4).2019.21

9. Government of Russian Federation. (2019). Kontseptsiya povysheniya effektivnosti biudzhetnykh raskhodov v 2019-2024 godakh. Rasporyazhenie ot 31 yanvaria 2019 № 117-r [The concept of increasing the efficiency of budget spending in 2019-2024. Order of January 31, 2019 No. 117-r.]. (In Russian). Retrieved April 4, 2020 from http://government.ru/ docs/35598/

10. Hryhorash, O., Korneyev, M. Leheza, Ye., Zolotukhina, L., \& Hryhorash, T. (2018). The development of small business as a source of formation of local budget revenues in Ukraine. Investment Management and Financial Innovations, 15(1), 132140. http://dx.doi.org/10.21511/ imfi.15(1).2018.12

11. Klatcer, E., \& Ivanina, T. (2019). Henderno-oriientovane biudzhet- uvannia: analiz program, yaki finansuiutsia $\mathrm{z}$ biudzhetu, $\mathrm{z}$ pozyt sii hendernoi rivnosti [GenderOriented Budgeting: An Analysis of Budget-Funded Programs from a Gender Equality Perspective]. In Henderne biudzhetuvannia v Ukraini (35 p.). Kyiv. (In Ukrainian). Retrieved April 4, 2020 from http://grbproject.org/wp-content/ uploads/2019/09/GRB-Manual.pdf

12. Lysiak, L. V., Kachula, S. V., Hrytsenko, O. V., Romenska, K. M., \& Deikalo, L. Ye. (2015). Biudzhetna skladova realizatsii dominantnykh napriamiv suspilnoho rozvytku [Budget component of realization of dominant directions of social development] (396 p.). Dnipropetrovsk: DSFA. (In Ukrainian)

13. Lukianenko, I. H. (2017). Systemnyi analiz formuvannia derzhavnoi polityky $v$ umovakh makroekonomichnoi destabilizatsi [System analysis of state policy formation in the conditions of macroeconomic destabilization] (464 p.). Kyiv: NaUKMA. (In Ukrainian)

14. Ministry of Finance of the Russian Federation. (2020). Informatsionnoe illiustrirovannoe izdanie "Ispolnenie federalnogo biudzheta $i$ byudzhetov byudzhetnoy sistemy Rossiyskoy Federatsii" [Informational illustrated publication "Execution of the federal budget and budgets of the budget system of the Russian Federation"]. (In Russian). Retrieved April 4, 2020 from https://www.minfin.ru/ru/ perfomance/budget/federal_budget/budgeti/2018/

15. Ministry of Finance of the Russian Federation. (2020a). Ispolnenie federalnogo byudzheta $i$ byudzhetov byudzhetnoy sistemy Rossiyskoy Federatsiii za 2019 god (predvaritelnye itogi) [Execution of the federal budget and budgets of the budget system of the Russian Federation for 2019 (preliminary results)]. (In Russian). Retrieved April 4, 2020 from https://www. minfin.ru/ru/perfomance/budget/ federal_budget/budgeti/2020/

16. Ministry of Finance of the Republic of Belarus. (2019). Osnovnye 
napravleniya byudzhetno-finansovoy i nalogovoy politiki Respubliki Belarus na 2020-2022 gody [The main directions of the fiscal and tax policy of the Republic of Belarus for 2020-2022]. (In Russian). Retrieved April 4, 2020 from http:// www.minfin.gov.by/upload/bp/ taxpolitic/04112019.pdf

17. Ministry of Finance of the Republic of Belarus. (2020). Byulleten ob ispolnenii konsolidirovannogo i respublikanskogo byudzhetov Ministerstva finansov Respubliki Belarus [Performance Bulletin consolidated and republican budgets Ministry of Finance of the Republic of Belarus]. (In Russian). Retrieved April 4, 2020 from http://www.minfin.gov. by/ru/budgetary_policy/bulletin/

18. Ministry of Finance of the Republic of Kazakhstan. (2019). Otchet ob ispolnenii respublikanskogo byudzheta [Report on the execution of the republican budget]. (In Russian). Retrieved April 4, 2020 from http://www.minfin.gov.kz/ irj/portal/anonymous? Navigation Target=ROLES://portal_content/ $\mathrm{mf} /$ kz.ecc.roles/kz.ecc.anonymous/kz.ecc.anonymous/kz.ecc. anonym_budgeting/budgeting/ reports_fldr/yearly_reports

19. Ministry of Finance of the Republic of Kazakhstan. (2019a). Statisticheskiy byulleten MF RK na 1 yanvarya 2020 goda [Statistical Bulletin of the Ministry of Finance of the Republic of Kazakhstan as of January 1, 2020]. (In Russian). Retrieved April 4, 2020 from http:// www.minfin.gov.kz/irj/portal/an onymous? NavigationTarget $=\mathrm{RO}$ LES://portal_content/mf/kz.ecc. roles/kz.ecc.anonymous/kz.ecc. anonymous/kz.ecc.anonym_budgeting/budgeting/reports_fldr/ statistical_bulletin_fldr

20. Ministry of Finance of Ukraine. (2013). Metodyka zdiisnennia porivnialnoho analizu efektyvnosti biudzhetnykh program, yaki vykonuiutsia rozporiadnikamy koshtiv mistsvykh biudzhetiv. Lyst vid 19.09.2013 № 31-05110-145/27486 [Methods of comparative analysis of the effectiveness of budget programs performed by local budget managers. Letter dated September 19, 2013 No. 31-05110-
14-5/27486]. (In Ukrainian). Retrieved April 4, 2020 from https:// www.ibser.org.ua/legislation/ zakonodavstvo-z-pmc/ocinkabyudzhetnyh-program

21. Ministry of Finance of Ukraine (2014). Ppo deiaki pytannia zaprovadzhennia prohramno-tsiliovoho metody skladannia ta vykonannia mistsevykh biudzhetiv. Nakaz vid 26.08.2014 p. № 836 [On some issues of implementing a programtargeted method of compiling and executing local budgets. Order dated August 26, 2014 No. 836]. (In Ukrainian). Retrieved April 04, 2020 from http://zakon2.rada.gov. ua/laws/show/z1103-14

22. Ministry of Finance of Ukraine. (2015). Pro zatverdzhennia typovykh form biudzhetnykh zapytiv dlia formuvannia mistsevykh biudzhetiv. Nakaz vid 17.07.2015 № 648 [On the statement of standard forms of budgetary inquiries to form local budgets. Order dated July 17, 2015 No. 648]. (In Ukrainian). Retrieved April 03, 2020 from https://zakon.rada.gov.ua/ laws/show/z0957-15

23. Ministry of Finance of Ukraine. (2018). Biudzhet Ukrainy 2017. Statystychnyi zbirnyk [Budget of Ukraine 2017. Statistical collection] (308 p.). Kyiv: MFU. (In Ukrainian). Retrieved April 4, 2020 from https://www.mof.gov. ua/storage/files/Budget $\% 20$ of $\% 20$ Ukraine\%202017\%20(publish).pdf

24. Ministry of Finance of Ukraine. (2019). Biudzhet Ukrainy 2018. Statystychnyi zbirnuyk [Budget of Ukraine 2018. Statistical collection] (310 p.). Kyiv: MFU. (In Ukrainian). Retrieved April 4, 2020 from https://www.mof.gov. ua/storage/files/Budget $\% 20$ of $\% 20$ Ukraine $\% 202018 \% 20$ (for $\% 20$ website).pdf

25. Ministry of Finance of Ukraine. (2019a). Informatsiia shchodo vykonannia Derzhavnoho ta Zvedenoho biudzhetiv Ukrainy [Information on the implementation of the State and Consolidated Budgets of Ukraine]. (In Ukrainian). Retrieved April 4, 2020 from https://www.mof.gov.ua/uk/ previous-years-budgets
26. Organisation for Economic Co-operation and Development. (2020). Public governance. Retrieved May 27, 2020 from http:// www.oecd.org/governance/

27. Radionov, Yu. D. (2019). Vydatky biudzhetu u zabezpechenni staloho socialno-ekonomichnoho rozvytku krainy [Budget expenditures in ensuring sustainable socio-economic development of a country]. Investytsii: praktyka ta dosvid - Investment: Practice and Experience, 16, 39-46. (In Ukrainian). Retrieved April 4, 2020 from http://www.investplan.com. ua/?op $=1 \& z=6790 \& \mathrm{i}=5$

28. Republic Budget Commission of the Republic of Kazakhstan. (2019). O respublikanskom byudzhete na 2020-2022 gody. Zakon Respubliki Kazakhstan ot 4 dekabria 2019 № 276-VI ZRK [About the republican budget for 2020-2022. Law of the Republic of Kazakhstan dated December 2019 No. 276-VI ZRK]. (In Russian). Retrieved April 4, 2020 from http://www.minfin.gov.kz/irj/ portal/anonymous?NavigationTar get=ROLES://portal_content $/ \mathrm{mf} /$ kz.ecc.roles/kz.ecc.anonymous/ kz.ecc.anonymous/kz.ecc.anonym_budgeting/budgeting/planing_fldr/law_about_resbudget

29. Republic Budget Commission of the Republic of Kazakhstan (2019a). Prognoz sotsialnoekonomicheskogo razvitiya Respubliki Kazakhstan na 2020-2024 gody. Protokol zasedaniya Respublikanskoy byudzhetnoy komissii ot 29 aprelia 2019 № 8 [Forecast of socio-economic development of the Republic of Kazakhstan for 2020-2024. Protocol of the meeting of the Republic Budget Commission of April 29 No. 8]. (In Russian). Retrieved April 4, 2020 from http://www.minfin.gov.kz/irj/ portal/anonymous?NavigationT arget=ROLES://portal_content/ $\mathrm{mf} / \mathrm{kz}$.ecc.roles/kz.ecc.anonymous/kz.ecc.anonymous/kz.ecc. anonym_budgeting/budgeting/ planing_fldr/main_macroeconomic_index

30. Sharov, O. M., \& Reznikova, O. O. (2019). Pidsumky Vsesvitnoho ekonomichnoho forumu u Davosi 
(2019): vysnovky dlia Ukrainy [Results of the World Economic Forum in Davos (2019): conclusions for Ukraine]. National Institute for Strategic Studies. (In Ukrainian). Retrieved May 25, 2020 from http:// old2.niss.gov.ua/content/articles/ files/1_Davos_2019-a5129.pdf

31. State Duma of the Russian Federation. (2019). O federalnom byudzhete na 2020 god i na planovyy period 2021 i 2022 godov. Federalnyy zakon ot 02.12.2019 № 380-FZ [On the federal budget for 2020 and for the planning period of 2021 and 2022. Federal Law of December 2, 2019 No. 380-FZ]. (In Russian). Retrieved April 4, 2020 from https://www.minfin.ru/ru/ perfomance/budget/federal_budget/budgeti/2020/

32. Treasury of Ukraine. (2019). Informatsiia pro zupynennia operatsii z biudzhetnymy koshtamy, provedeni Derzhavnoiu kaznacheiskoiu sluzhboiu Ukrainy rozporiadnikam (oderzhuvacham) biudzhetnykh koshtiv [Information suspension of operations with budget funds conducted by the State Treasury Service of Ukraine to managers (recipients) of budget funds]. (In Ukrainian). Retrieved April 4, 2020 from https://www.treasury.gov.ua/ua/ timeline?\&type=posts\&category_ id $=6$

33. Verkhovna Rada of Ukraine. (2010). Biudzhetnyi kodeks Ukrainy. Zakon Ukrainy vid 08.07.2010 №2456-VI [Budget Code of Ukraine. Law of Ukraine as of July 8, 2010 No. 2456-VI].

(In Ukrainian). Retrieved April 4, 2020 from https://zakon.rada.gov. ua/laws/show/2456-17

34. Verkhovna Rada of Ukraine. (2018). Pro vnesennia zmin do Biudzhetnoho kodeksu Ukrainy shhodo zaprovadzhennia seredniostrokovoho biudzhetnoho planuvannia. Zakon Ukrainy vid 06.12.2018 №2646- VIII [On amendments to the Budget Code of Ukraine regarding the introduc- tion of the medium-term budget planning. Law of Ukraine dated December 6, 2018 No. 2646-VIII]. (In Ukrainian). Retrieved April 4, 2020 from https://zakon.rada.gov. ua/laws/show/2646-19\#n5

35. Verkhovna Rada of Ukraine. (2020). Pro Derzhavnyi biudget Ukrainy. Zakon Ukrainy vid 03.04.2020 № 294-IX [On the state budget of Ukraine. Law of Ukraine dated April 3, 2020 No. 294-IX]. (In Ukrainian). Retrieved April 4, 2020 from https://zakon.rada.gov. ua/laws/show/294-IX

36. Zubenko, V. V. (Ed). (2017). Planuvannia ta vykonannia mistsevykh biudzhetiv na osnovi prohpamno-tsiliovoho metodu [Planning and execution of local budgets based on program-targeted method] (144 p.) (6th ed.). Kyiv. (In Ukrainian). Retrieved April 4, 2020 from https:// www.ibser.org.ua/sites/default/ files/170x240_19_1.pdf 